\title{
Hemingway's Obsession with Death and Violence
}

\author{
R. Savitha, Laxmi Dhar Dwivedi
}

\begin{abstract}
Ernest Miller Hemingway, one of the best known and most influential of modern American writers. Hemingway will be remembered for his fictional technique, his dialogue consisting of short, concrete statements, his passionate search for the exact world which will express an exact and limited truth, his experiments with prose rhythms which have transformed the staccato rattle of his early writing into the liquid, cadenced ripple of some of his work. The present work intends to make a study of Hemingway's Obsession with Death and Violence in his works.

Keywords: Death, Violence, Obsession.
\end{abstract}

\section{INTRODUCTION}

\section{Death}

Throughout his life and career as a literary artist, Hemingway showed a strong interest in death. Different critics have given it various names. Some have called it an obsession with death, while others have referred it as a death wish, the cult of death etc. One critic has even gone to the extent of stating that in reality Hemingway has only one theme - death. Perhaps no Protestant can pretend to understand the catholic mind, and it is from Catholicism, perhaps, that Hemingway's constant pre occupation with the theme of death arises". In this conjecture, the critic has given us the truth about Hemingway. Death is a recurring and constant subject in his works, even figuring in their names as for example, Death in the Afternoon. Further, in this novel, Hemingway makes a point to ridicule the Englishman who wrote; 'Life is real; life is earnest, and the grave is not its goal'. Hemingway further points out that the Spanish think a great deal about death and even when they have a religion, they have one which is based on the view that human life is short, very short when compared to the reality of death. The Spanish people's interest in death is an intelligent View and it explains their relishing and being so taken with the game of bullfighting. Death for them is a necessary element of life and there is nothing that points towards an obsessive nature or any element of morbidity in their interest. As Hemingway himself declares is 'Death in the Afternoon deaths is: the unescapable reality, the only thing any man may be sure of', no do the Spanish believe. Hemingway's view therefore is that death needs to be accepted as an integral part of life, a necessary evil. And death is at the centre of Hemingway's world and so needs to be accepted as an integral part and parcel of life. Death is the focal point around which life revolves and death awaits man somewhere or the other, no matter where and how he may start. Death is that

Revised Version Manuscript Received on 16 September, 2019.

R.Savitha M.A, M.Phil, Research Scholar, School of Social Science and Languages, VIT University, Vellore, Tamilnadu, India

Dr. Laxmi Dhar Dwivedi Ph.D., Associate Professor of English, School of Social Science and Languages, VIT University, Vellore, Tamilnadu, India. element that makes life a complete whole. Life is precious only because of the lurking presence of death in every corner.

\section{Violent Death}

Hemingway was obsessed with death but more than that he was interested in violent death. It was a subject which he admitted, he wanted to write most about. In Death in the Afternoon. Hemingway in the very beginning informs the readers that the bull-fights in Spain had attracted and induced him to come to Spain because after the war Spain and the bull-fighting arena was the only place where he could study violent death.

Hemingway in the course of his wide reading had found that many other authors had attempted to write on the subject of violent death but these writers after beginning had faltered in their grasp of the subject and failed. They had been able only to convey blurred visions rather than clear and sharp impression and emotions. Hemingway therefore wanted to portray violent death and he defends his obsessive interest in the subject. Such a defense can also be found in the text Death in, the Afternoon, wherein he converses with an Old Lady and says:

Madam, all stories, if continued for enough rend in death, and he is no true story teller who would keep that from you. There is no lonelier man in death, except the suicide, than the man who has lived many years with a good wife and then outlived her of two people love each other also covers Hemingway's other works from A Farewell to Arms to Across the River and into the Trees. Tragedy, violent death was the subject of Hemingway's work. One of his characters says "By my troth, I care not; a man can die but once; we own God a death and let it go which way it will; he that dies this year is quit for the next". Thus Hemingway's belief in death itself served as a charm, a talisman for the people, the professional soldiers, matadors, and others who are repeatedly confronted with death who inhabit Hemingway's world. They are constantly confronting death, the consciousness of immortality is mortality that Hemingway was in the quest for, and which he strongly wished to share with his readers, he could find only in the world of matadors and bull-fighting.

\section{MAN'S INDIVIDUALITY MADE CONSCIOUS THROUGH DEATH}

Hemingway's doctrine calls that man should accept death as an integral part of life and this was his means of insisting on man's individuality.

American culture in a way facilitates and promotes that the individual loses his identity and in the outward movement of the democratic makes of people the notion of the cycle of individual life has disappeared, all these achieved mainly through the devices of American culture that obscures

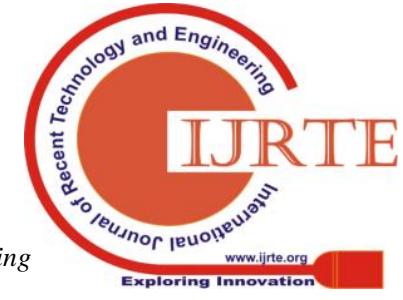


the reality of death. The values of life, instead of being measured as on according to the light of individual experience is simply given over of the general public to give its opinion on. Though his earliest fiction is not lacking of the elements, accidents and events of death, his later novels seem all the more obsessed with death and show how an individual lives life struggling against the forces attempting to clarify the values of life, the codes he lives by, all the while however waiting for death to come. This idea that death is near, or-that death is awaiting all individual human beings at one point or another is an important reason for the men and women in Hemingway to cultivate his own private view of how in the game of life he has lived life according to the rules or in defiance of the rules.

\section{BULL-FIGHTING CELEBRATION OF DEATH}

Death in the Afternoon a semi fictional novel dealt with the art and game of bull-fighting. The novel is in fact a chronicle of the various aspects of the game. Bull-fighting is considered by most of the civilized world as a decadent and cruel sport. But Hemingway wished to portray that is in fact not just a game but a religious ritual. This view wholly different from the View held by the people of his homeland was important for him and he wished to assert his attainment of a different outlook of life. He was rebelling against death as he tells us in the novel. He would destroy death. He would do this like the metaphysical poets by using metaphors. He would prove that death was but merely a stage from where one progressed on the new order of being. According to Hemingway's philosophy, the bull in bull-fighting stands for death and the matador's killing the bull signified a ritual victory over death. And in this way also served as a rejection to the theory that there were no destructive forces within the human personality and which in effect constitute the denial of Eros. Hemingway took an anti-intellectual stance and his glorifying and celebrating death in bull-fighting can be seen as part of this stance. Freud presented the idea that neuroses are usually and frequently the result of a civilization imposing upon the individual cultural ideals that frustrate primitive impulses of aggression and self destruction. To this concept and idea is related Hemingway's idea. His constant concern of the need to confront death, reflected in his desire for an interest in bull-fighting and his need to accept death, danger and violence as part of human life. Modern social psychologist feels that culture itself is neurotic due to excessive repression and Hemingway's view is more in tune with this view rather than Freud's view.

\section{VARIOUS DEATHS AS PORTRAYED IN HIS NOVELS}

Hemingway portrays death in a variety of ways in his different novels. In The Sun Also Rises, the image he points is Romero facing the bull, alone is the sun lit arena. The bull which is the carrier of death becomes poignantly symbolic. Romero's encounter with death is what is at the centre of the celebration of life and his death serves as the climax to the fiesta in the novel. In A Farewell to Arms Catherine and Henry talk about the different deaths faced by a coward and a brave man and how man according to their response to death are differentiated into the brave and the coward. Henry quotes that 'the coward dies a thousand death, the brave but one'.
Catherine doesn't agree and says that "the brave dies perhaps two thousand deaths if he's intelligent. He simply doesn't mention them". To this Henry says "I don't know. Its hard to see inside the head of the brave", thereby also admitting that he is not bravo. However in the end neither Henry nor Catherine are shown as being afraid of death. Catherine on the verge of' death says 'its only a roll on trick" and Henry accepts it, thereby bringing them closure to the view as impressed earlier, that the world killed everyone impartially. And in a way endorsing Hemingway's view that the fear of death was the ultimate test of manhood whether he went to observe the inside of ahead or not.

This concept is carried on further in the short story The Short Happy Life of Francis Macomber. Wherein Francis after wounding the lion cannot go after it, into the high grass because of his fear of death but eventually learns the code of courage. In For Whom the Bell Tolls, Robert Jordan is severely wounded and in a way impeding the escape of his comrades and when he realised that death is inevitable, he urges his comrades to go on without him. He would lay there and cover their escape. His lover Maria tries to insist that he accompanies them. But Jordan says, "Nay, Listen. People cannot die together. Each must die alone." Thus Jordan who is acutely aware of the impending death brings forth the idea that dying is a lonely act. That one has to die alone. This awareness makes Jordan squeeze into three days, seventy years of a lifetime and he is absolutely determined to live life fully and to experience every little detail, every single moment to the hilt, fully, totally and to follow the same process in his meeting with death. He has successfully completed the mission that he was originally sent for. $\mathrm{He}$ enacts the drama of his own death with the same perfection as he carries out his mission. His death is a lonely death and is one of the most beautiful deaths in modern American literature. Jordan's death raises act of dying to a ritual and an art.

\section{OBSESSED WITH VIOLENCE AND HORROR}

Hemingway's world of fiction has so much violence, brutality and horror that some critics even refer to him as a 'caveman' in the field of literature. But to assume that he is a man given to violence and horror tactics would be wrong because he is also a sensitive responsive man. $\mathrm{He}$ is as sensitive to the modern man's interest in the problems regarding the meaning and values of human life. This view is best contained in the statement that his heroes are. "Brutal and reckless by day but wistful as little boys when alone at night with the woman they love. Even in his worst characters Hemingway always imbues some sensitivity that makes for a curious element in that character. Hemingway's own attitude to these characters is one of kindness and respect and mercy. Sometimes he gives the reader the impression also of being a hypersensitive man who has been hurt most terribly by life and in order to convince himself that he can bear or 'lake it' as he says, dwells upon a number of horrible things that he may or may not experience. This attitude has been partly explained away as due to his awful experiences in the first world war and partly due to his being part of' the lost generation, a generation whose hopes, aspirations and illusions of any kind wore brutally

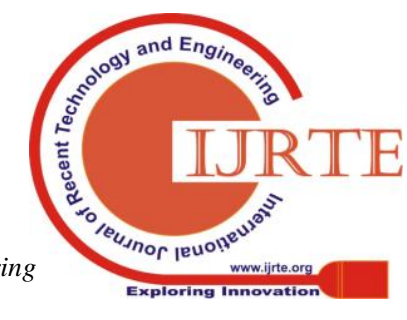


destroyed by the war. But to emphasis the point, all these explain his obsession with violence and horror partly not fully. If there had been no war at all, there most probably would have the dull, pessimistic view that Hemingway had of the twentieth century world. This is a conclusion drawn from the evidence found in his first published work, the collection of short stories "In Our Time". These stories are based on Hemingway's experiences as a boy and even here, events and accidents illustrating that he had met terror and horror even during his boyhood are clear. This is true especially on the hunting and fishing trips he went on to do with his father in Michigan. These experiences left an indelible mark on his mind and he never quite forgot the' i for the rest of his life. Maybe he was thrown into deep shock by his father's suicide. However, he was determined not to run away from any of the darker aspects of life. He did not wish to evade any kind of issue rather he wanted to tackle them head on. On the other hand he did not wish to concern himself with any mundane everyday matter. He wanted to be challenged by the ultimate crisis of human soul as if confronted with an ultimate challenge. Therefore, he does not simply present the pleasant and beautiful aspect of life, he dissects all the grim realities of life and presents the horror and violence that life in actuality is. In this respect then Hemingway is a profoundly moral writer. However he does not endorse any great moral code of conduct because it remains limited as his definition is simply what makes you feel good afterwards.

\section{PORTRAYAL OF MORAL DISORDER}

The world that Hemingway usually portrays is a world of drunkenness, casual and indiscriminate sexuality. This ugly world is however not devoid of pity. But for all his portrayal of a bleak world, his books are not immoral books. Just because it portrays the moral disorder and chaos induced by the war it cannot be classed so rather by virtue of that portrayal there may be something good and wholesome in that book. On the other hand, to take the example of Lady Brett Ashley in The Sun Also Rises, it may be said that she indulges in free and frequent sexual encounters and yet she gives up Romero, the young bull-fighter as she feels that she may poison his youth and his prospects with her own corruption. But because of her already strongly etched negative character it is difficult to feel any admiration for her sacrifice. Though her act is unquestionably right, but one is not very sure because of the nature other character. In this novel Hemingway presents the post war expatriates who spend a life of idle wastefulness. And is probing the human predicament with all its ugly faces has portrayed a Terrible new world where people have sold their souls to the dive!

The atmosphere of desperate futility can also be seen in Hemingway's next novel, A Farwell to Arms. Based as it is on the First World War the grim reality the terror and horror associated with the war finds its way here. The here from a casual participant becomes an active participant and eventually disgusted by the cruelties of war makes a "separate peace" and deserts the war. On the other hand is Hemingway's portrayal of the relationship between Henry and Catherine. Beginning casually, it develops into a deeper love though still of sensual kind. After Henry's desertion they run away together and though not yet legally or religiously married attains unparalleled romantic bliss in the Mountains of Switzerland. However, the idyll is short lived, it comes to an abrupt and tragic end with Catherine's death after giving birth to a baby. The horror that Hemingway portrays here is not so much physical as it is mental. The feeling conveyed is pathetic horror that man is completely helpless in the face of the unbending forces of nature. A similar examination of human relationship can be studied in the various relationships between the characters of the novel For Whom the Bell Tolls Hemingway believed in the doctrine of the freedom of the Will and this doctrine is that on which most of his relationships are based and the doctrine according to which he pondered these relationships. In this novel Robert Jordan and Maria are under the constraint of the war and yet they come together.

After their encounter, Pilar, the old guerilla's wife warns Jordan because Maria came to him of her own accord. Jordan was not to think of it lightly, especially since they were in the midst of the Spanish Civil War and marriage was out of question. Jordan then ponders over the cruel destiny of people in this world, especially the fate of lovers who has to live a lifetime within a few days. Further, in Maria's case, who has already suffered such cruelty and horror at the hand of the fascist, there are other complications to such a compressed life. Because of her history, it is her urgent need to be reconciled to life and its outrageous demands if at all she needs to survive as an emotional being.

\section{A LOOK AT VARIOUS CHARACTERS}

A study of Hemingway's themes requires that we look into the van lous characters through whom these themes are portrayed. Catherine and Maria as female characters have a lot of appeal. However, they are rather too submissive females whose every action is carried out with the calculated aim of pleasing her man. Because of this, critics have called them more personification of an erotic fantasy and some have even gone to the extent of accusing Hemingway of infantilism in his treatment of love. His female characters are closely akin to the movie stars that come in Jordan's dreams. Therefore, the charge thrown at Hemingway is that his novels should deal with something that is a little higher than mere sensual encounters. He should have portrayed love affairs. A little more of the tender feelings associated with life would have done much to relieve the atmosphere of' gloom and bitterness. In A Farewell to Arms, the Priest serves to lend religious significance to Henry's quest for meaning, some kind of certitude in his life. A critic has pointed out that 'In the end, with the death Of Catherine, Frederic discovers that the attempt to find a substitute for universal meaning in the limited meaning of the personal relationship is doomed to failure," Thus, the presence of the priest and his importance diminishes if at all no meaning can be found. In the novel To Have and Have Not, the central character Harry Morgan is all said and done a criminal and therefore he has an aesthetically unsatisfactory history. Both he and his coarse wife's morals are not of a satisfactory nature. Thus, because of this, even though sympathy and pity is aroused at their sad plight, we cannot really sympathies or in any way justify Morgan's criminal acts. Therefore Hemingway's portrayal of their bleak world and his attempt to glorify it does not sit down well with the readers. Robert Jordan of For Whom the Bell Tolls, is an exception in the sense that most of Hemingway's heroes seem to

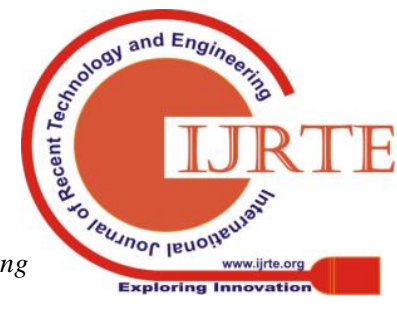


drift into war and the world of violence, but he is in the Spanish Civil War by choice. He has not come to join the revolution as an adventure. He is in Spain and actively helping the liberalist guerillas because he firmly believes in the liberty of human beings and that freedom for humanity is going to be won or lost here as 'the loss of liberty in one place threatens the existence of liberty elsewhere.'

\section{CONCLUSION}

The themes of Hemingway therefore are all of a bleak nature. And in portraying death, violence and horror, even his characters all gloomy and desperate characters. And especially since most of his characters meet with violent and horrific deaths, Hemingway's obsession with death is well proved. Right from Catherine, to Francis and Harry Morgan, Jordan and a host of other characters meet with violent torturous deaths. Therefore, it can be concluded that the single theme Hemingway dealt with and came back to again and again was death. However, this is not / the whole truth. The explanation to this is that Hemingway was so much interested in death because he was greatly attracted and interested in life. And to understand life completely one has to accept death as an essential part of life. If man wishes to conquer life, he should conquer death and "he wishes to conquer death he should conquer and achieve mastery over life. Hemingway's themes are thus two-fold, death and 1ife. By taking death and life equally serious, he is able to establish the close affinity and closeness between the two themes. And by this the fact that his fascination with death is not morbid is established. Further, another fact about his art is established. That is art is an integral part. His vision of life and death forms the basic truth or the elemental root from which his art springs. His various bases concerning character, situation, style and philosophy are all developed on the basis of this vision and acquire their complex texture from it. Thus, Hemingway's obsessions with death and therefore violence and horror has its logical reason and are simply not signs of his morbidity or post war desperation or depression.

\section{REFERENCES}

1. Edward Wagenknecht (1952). Cavalcade of American Novel

2. Kumar, N. S. Relation of Nature and Humans as Represented in Ernest-Hemingway's "The Old Man and the Sea”.

3. Brucolli, M. (Ed.). (1970). Ernest Hemingway: Cub Reporter. University of Pittsburgh Press.

4. Molina, J. E. S. The Role of Literature in the Formation of Intercultural Awareness.

5. Chen, L. T. (Ed.). (1989). Hemingway Short Stories. Beijing: World Book Publishing House.

6. Godavarthy, M. The English Classroom: Scope and Space for Motivation.

7. Hemingway, E. (1926). The Sun Also Rises. New York: New York Charles Scribner's Sons Press.

8. Tripathi, A. B. H. A. (2016). The old man and the sea: A study of interdependence of human relationship. International Journal of Humanities, Arts, Medicine and Sciences, 4(2), 183-186.

9. Baker, C. (1972). Ernest Hemingway: The Writer as artist. Princeton: Princeton University Press.

10. Dong, H. X. (1989). A Critical Biography of Hemingway. Beijing: China Social Sciences Publishing House. 